\title{
In vitro action of Mimosa caesalpinifolia ketone extract on Haemonchus contortus and Trichostrongylus colubriformis
}

\section{Ação in vitro do extrato cetônico da Mimosa caesalpinifolia sobre Haemonchus contortus e Trichostrongylus colubriformis}

\author{
Danilo Rodrigues Barros Brito ${ }^{1 *}$; Livio Martins Costa Júnior ${ }^{2}$; \\ João Luis Garcia ${ }^{3}$; Suzana Gomes Lopes ${ }^{4}$; \\ Giselle Cutrim de Oliveira Santos ${ }^{5}$; João Victor da Silva Sousa ${ }^{6}$
}

\begin{abstract}
This study aimed to evaluate the in vitro anthelmintic activity of Mimosa caesalpinifolia (sabiá) ketone extract, which is rich in condensed tannins (CT), on Haemonchus contortus and Trichostrongylus colubriformis. The leaves and stems of M. caesalpinifolia were collected, dried in the shade, and ground to a dry powder from which ketone extracts were obtained for in vitro assays. The extracts were diluted in 5\% acetone and PBS to concentrations in the range $0.25-2.80 \mathrm{mg} \mathrm{mL}^{-1}$ and the inhibition of egg hatchability was assayed. Feces collected from goats naturally infected with $H$. contortus $(55 \%)$ and $T$. colubriformis $(45 \%)$ were macerated and the helminth eggs were collected to conduct in vitro egg hatchability tests. Nematode larvae collected from the feces were used for a larval exsheathment inhibition assay of $M$. caesalpinifolia leaf and M. caesalpinifolia leaf and stem ketone extracts at concentrations of 0.6 and $1.2 \mathrm{mg} \mathrm{mL}^{-1}$; three replicates were performed for each concentration. PBS was used as a negative control. Polyvinylpolypyrrolidone (PVPP) was added to the extracts to assess the effect of phenolic compounds on anthelmintic activity. An inhibitory effect of $80.7 \%$ and $82.3 \%$ was observed on hatchability after treatment with 1.0 and $2.0 \mathrm{mg} \mathrm{mL}^{-1} \mathrm{M}$. caesalpinifolia leaf ketone extract, respectively. An inhibition rate lower than $75 \%$ was observed for $1.0 \mathrm{mg} \mathrm{mL}^{-1} M$. caesalpinifolia leaf and stem ketone extract. The M. caesalpinifolia leaf ketone extract larval exsheathment assay resulted in inhibition of $97.3 \%$ and $99.8 \%$ at concentrations of 0.6 and $1.2 \mathrm{mg} \mathrm{mL}^{-1}$, respectively. For the leaf and stem ketone extract, the larval exsheathment inhibition was $94.3 \%$ at $1.2 \mathrm{mg} \mathrm{mL}^{-1}$. The leaf and leaf and stem extracts showed no inhibitory effects on larval exsheathment after the addition of PVPP. These results showed that cuticular loss was related to the action of the phenolic compounds in the $M$. caesalpinifolia extracts. M. caesalpinifolia leaf ketone extract inhibited egg hatchability, but the leaf and stem extract showed lower efficiency, which indicated a greater abundance of active compounds in the leaves. The $M$. caesalpinifolia ketone extracts were effective in the inhibition of larval exsheathment at the highest concentration tested. Based on these results, in vivo studies should be performed to demonstrate the anthelmintic activity of this plant in goats.
\end{abstract}

Key words: Gastrointestinal Nematodes. Goats. Polyphenols. Condensed tannin.

\footnotetext{
${ }^{1}$ Prof. Dr., Laboratório de Sanidade Animal, Instituto Federal do Maranhão, IFMA, Campus Maracanã, São Luís, MA, Brasil. E-mail: danilobrito@ifma.edu.br

2 Prof. Dr., Laboratório de Controle de Parasitos, Departamento de Patologia, Universidade Federal do Maranhão, UFMA, São Luís, MA, Brasil. E-mail: livioslz@yahoo.com

${ }^{3}$ Prof. Dr., Departamento de Medicina Veterinária Preventiva, Centro de Ciências Agrárias, CCA, Universidade Estadual de Londrina, UEL, Londrina, PR, Brasil. E-mail: joaoluisgarcia10@gmail.com

${ }^{4}$ Prof $^{\mathrm{a}} \mathrm{Dr}^{\mathrm{a}}$, Curso de Licenciatura em Educação do Campo/Ciências da Natureza, Universidade Federal do Piauí, UFPI, Campus Senador Helvídio Nunes de Barros, Picos, PI, Brasil. E-mail: suzanagms.lopes@gmail.com

5 Discente de Doutorado em Biotecnologia, UFMA, São Luís, MA, Brasil. E-mail: giselle.cutrim@gmail.com

${ }^{6}$ Discente de Licenciatura em Ciências Agrárias, IFMA, São Luís, MA, Brasil. E-mail: jvss14@hotmail.com

* Author for correspondence
} 


\section{Resumo}

Este trabalho teve como objetivo avaliar a atividade anti-helmíntica in vitro do extrato cetônico, rico em Tanino Condensado (TC) de Mimosa caesalpinifolia (sabiá) sobre Haemonchus contortus e Trichostrongylus colubriformis. Foram coletadas folhas e caules, secas a sombra por sete dias e moídas. O pó seco das folhas e caules foi utilizado para obtenção dos extratos cetônicos e realização dos testes in vitro. Os extratos foram diluídos em acetona $5 \%$ e PBS em concentrações entre 0,25 e 2,80 mg mL $\mathrm{mL}^{-1}$ para realização do teste de inibição da eclodibilidade de ovos. Fezes coletadas de caprino infectado com H. contortus (55\%) e T. colubriformis (45\%) foram maceradas e os ovos dos helmintos recuperados, e testes in vitro de eclodibilidade dos ovos realizados. Larvas dos nematódeos recuperadas das fezes foram utilizadas para o teste de inibição do desembainhamento larvar com os extratos de folhas, e folhas com caule de $M$. caesalpinifolia em concentrações de 0,6 a $1,2 \mathrm{mg} \mathrm{mL}^{-1}$ com três repetições para cada concentração. O controle negativo foi realizado com PBS. Polivinilpolipirrolidona (PVPP) foi adicionado aos extratos para verificar o efeito de compostos fenólicos na atividade anti-helmíntica. No extrato cetônico de folha de $M$. caesalpinifolia, nas concentrações 1,0 e 2,0 $\mathrm{mg} \mathrm{mL}^{-1}$, foi observado uma taxa de inibição de eclodibilidade dos ovos de 80,7 e $82,3 \%$, respectivamente. O extrato cetônico de folha com caule da $M$. caesalpinifolia apresentou uma taxa de inibição inferior a $75 \%$, na concentração de 1,0 $\mathrm{mg} \mathrm{mL} \mathrm{mL}^{-1}$. O extrato cetônico das folhas de M. caesalpinifolia inibiu 97,3 e 99,8\% o desembainhamento das larvas na concentração de 0,6 e 1,2 $\mathrm{mg} \mathrm{mL}^{-1}$, respectivamente. Para o extrato cetônico da folha com caule, o desembainhamento larvar foi inibido em 94,3\% na concentração de 1,2 $\mathrm{mg} \mathrm{mL}^{-1}$. Extratos da folha e folha com caule com PVPP não foram capazes de inibir o desembainhamento das larvas. Podemos afirmar que a perda cuticular está relacionada com a ação de compostos fenólicos presentes nos extratos de M. caesalpinifolia. O extrato cetônico da folha de M. caesalpinifolia inibiu a eclodibilidade dos ovos, entretanto o extrato da folha e caule apresentou eficiência inferior, demonstrando que os compostos ativos estão mais presentes nas folhas. Para a inibição do desembainhamento larvar os extratos cetônicos da M. caesalpinifolia foram eficazes na maior concentração testada. Com esses resultados, pesquisas in vivo devem ser realizadas para comprovação da atividade anti-helmíntica dessa planta em caprinos.

Palavras-chave: Nematoides gastrintestinais. Caprinos. Polifenois. Tanino condensado.

\section{Introduction}

Gastrointestinal nematode parasitism is one of the main limiting factors of small ruminant exploitation in tropical and temperate areas, resulting in low productivity and high mortality (COSTA JÚNIOR et al., 2005).

The control of gastrointestinal nematodes in small ruminants is mostly performed through repeated treatment of the animal with wide spectrum anthelmintic drugs (AMARANTE et al., 1997; MUNN, 1997). However, the detection of isolates of gastrointestinal nematodes with multiresistance to the main classes of available treatment drugs has become a global phenomenon (KAMINSKY et al., 2008); it has resulted in serious issues in ruminant breeding and even precluded their production in some regions (BLAKE; COLES, 2007).
Tannins are a group of secondary metabolites produced by superior plants mainly to combat herbivory. Condensed tannins (CT) consist of flavan-3-ol coupled units that may exist as isolated dimers or as compounds with a high degree of polymerization (ROUTABOUL et al., 2006). Although the anthelmintic efficiency of CT has been demonstrated, the results of previous studies are inconsistent. Thus, the identification of abundant new sources of CT in specific regions is necessary.

Mimosa caesalpinifolia Benth., commonly known as sabiá, is a tanniniferous plant that occurs naturally in several states of the Northeast region of Brazil. Characterized by rapid growth, high regeneration capacity, and drought resistance, it is widely consumed by small ruminants in the rainy season and has also been used as food supplement during shortage periods (BARBOSA, 1997). It is 
a leafy tree of up to seven meters in height with aculeate branches, although unarmed forms may occur (BRAGA, 1976; COSTA, 1983; LIMA, 1996; MAIA, 2004).

The study of plants with anthelmintic activity has increased in the last decades with the aim of developing more effective products with lower residues for the agricultural market. Therefore, this study aimed to assess the in vitro anthelmintic activity of CT from M. caesalpinifolia (Sabiá) on Haemonchus contortus and Trichostrongylus colubriformis.

\section{Material and Methods}

\section{Collection of plant material and extract preparation}

The leaves and stems of M. caesalpinifolia were harvested during the dry season in October 2012 at the following coordinates: $2^{\circ} 37^{\prime} 01^{\prime \prime} \mathrm{S}$; 44 $4^{\circ} 16^{\prime}$ 19 " W. The exsiccates were prepared, identified, and deposited in the Ático Seabra Herbarium of the Federal University of Maranhão (voucher number 101).

The collected leaves and stems were dried for 7 days in the shade and ground in a Wiley mill of 0.25 -mm width.

Ketone extracts were obtained by the addition of dried powder $(200 \mathrm{mg})$ to $70 \%$ acetone $(10 \mathrm{~mL})$ (MAKKAR, 2003). The mixture was sonicated for $20 \mathrm{~min}$ and acetone was evaporated from the extract using a rotary evaporator at a temperature of $45^{\circ} \mathrm{C}$. The solution was then washed four times with dichloromethane $(500 \mathrm{~mL})$ and separated using a separating funnel. The obtained extracts were dried and stored under refrigeration. The total phenols, total tannins, and condensed tannins were evaluated using the Folin-Ciocalteu method (MAKKAR, 2003) and the HCl-butanol method (PORTER et al., 1986).

\section{Infected eggs and L3 larvae collection}

Feces were obtained from donor goats experimentally infected with a mixture of $H$. contortus (55\%) and T. colubriformis (45\%). The eggs from gastrointestinal nematodes were purified from fecal samples according to the method of Bizimenyera et al. (2006) and incubated at $27{ }^{\circ} \mathrm{C}$ for 7 days. Feces were cultured according to the technique described by Roberts \& O'Sullivan, following the method of Ueno and Gonçalves (1998), for recovery of third stage larvae (L3). Larvae were stored at $4{ }^{\circ} \mathrm{C}$ for a maximum of 2 months prior to the assays.

\section{Egg hatchability assay}

The assay was based on the method described by Coles et al. (1992). The extracts were diluted in 5\% acetone to produce final concentrations of $0.25,0.5$, 1, 2, and $2.8 \mathrm{mg} \mathrm{mL}^{-1}$ M. caesalpiniifolia leaf extract and $0.25,0.5$, and $1 \mathrm{mg} \mathrm{mL}^{-1}$ leaf and stem extract. Approximately 100 eggs were placed in each well of a 24-well plate and different concentrations of extracts were added. The eggs were then incubated in a BOD incubation $\left(27^{\circ} \mathrm{C}\right.$ and UR $\left.>80 \%\right)$ for $48 \mathrm{~h}$. After incubation, lugol was added to each well and the eggs and the L1 larvae were quantified by using inverted microscopy. The percentage inhibition of hatchability was calculated. Four replicates were performed for each concentration tested; the negative control was $5 \%$ acetone.

The percentage of egg hatchability was calculated by using the following equation: [number of larvae/ (number of eggs + number of larvae)] $\times 100$.

\section{Larval exsheathment inhibition assay}

The assay was performed according to Bahuaud et al. (2006). Forty-eight hours before the experiment, larvae viability was verified by using the Baermann technique. The extracts were diluted in 3\% dimethylsulfoxide (DMSO). The effect of the 
M. caesalpinifolia leaf and leaf with stem extracts at concentrations of 0.6 and $1.2 \mathrm{mg} \mathrm{mL}^{-1}$ were analyzed. The negative control was phosphate buffer solution (PBS, 0.1 M phosphate, $0.05 \mathrm{M} \mathrm{NaCl}, \mathrm{pH}$ 7.2). One thousand L3 larvae were incubated for $3 \mathrm{~h}$ at $22{ }^{\circ} \mathrm{C}$ in a BOD incubator and exposed to the two extracts at different concentrations. The larvae were subsequently washed with PBS and centrifuged three times ( $2318 \mathrm{~g}$ for $5 \mathrm{~min}$ ).

Approximately 100 L3 larvae were added per well of a 24-well plate and then submitted to artificial exsheathment through contact with $0.015 \%$ sodium hypochlorite solution diluted in PBS; three replicates were performed for each concentration. The larval exsheathment process was monitored at 10, 20, 40, and $60 \mathrm{~min}$ at different experimental concentrations by observing under inverted microscope, and interrupted every $20 \mathrm{~min}$ by the addition of lugol into the wells. Additionally, the effects of the extract were studied in the presence of polyvinylpolypyrrolidone (PVPP Sigma $\left.{ }^{\circledR}\right)$, an inhibitor of tannins and other polyphenols. The extracts were preincubated overnight with 50 mg mL-1 PVPP at $4{ }^{\circ} \mathrm{C}$ (ALONSO-DIAZ et al., 2008) and then tested as described above. The percentage of larval exsheathment in each treatment was determined by the expression [number of L3 exsheathed/(number of L3 with sheath + number of
L3 exsheathed] $) \times 100$.

The data on larval exsheathment were subjected to analysis of variance and the means were compared by Tukey's test. The calculations were performed using the statistical software InStat (GraphPad Software Oberlin, San Diego-CA, USA). The IC50 (inhibitory concentration at which the response was reduced by half) for the larval exsheathment assay was calculated by non-linear regression analysis using GraphPrism (version 5.0).

When the control value was below $10 \%$ in the egg hatchability and larval exsheathment inhibition assays, the values were corrected using the Abbott formula (1925), given below:

$\mathrm{Cm}(\%)=\% \mathrm{Om}-\% \mathrm{Ctrlm} \times 100$, where:

$100-\% \mathrm{Ctrlm}$

$\mathrm{Cm}=$ Corrected mortality

Om $=$ Observed mortality

Ctrlm $=$ Control mortality

\section{Results and Discussion}

The results of the quantification analysis of polyphenols in the $M$. caesalpinifolia leaf and leaf and stem powders are shown in Table 1.

Table 1. Percentage of polyphenolic compounds present in the leaf and leaf and stem of Mimosa caesalpinifolia (São Luís-MA, October, 2013).

\begin{tabular}{ccc}
\hline \multirow{2}{*}{ Polyphenolic Compounds } & \multicolumn{2}{c}{ Part of the plant } \\
\cline { 2 - 3 } & Leaf $(\%)$ & Leaf and stem (\%) \\
\hline Total Phenols & 14.38 & 7.49 \\
Total Tannins & 9.48 & 5.50 \\
Condensed Tannins & 8.45 & 5.46 \\
\hline
\end{tabular}

M. caesalpinifolia leaf and stem ketone extract showed anthelmintic activity in the egg hatchability assay. The highest inhibitory effect was observed at $2 \mathrm{mg} \mathrm{mL}^{-1}$ for the leaf extract, while the highest efficiency for the leaf and stem extract was observed at $1 \mathrm{mg} \mathrm{mL} \mathrm{m}^{-1}$ (Table 2). The assays with the leaves and stem ketone extract could not be performed at 2 and $2.8 \mathrm{mg} \mathrm{mL}^{-1}$ concentrations owing to the difficulty of visualization in the 24 -well plate. The negative control, performed with $5 \%$ acetone in triplicate, showed an inhibition rate of only $5.3 \%$. 
At 1 and $2 \mathrm{mg} \mathrm{mL}^{-1}$, the leaf extract inhibited egg hatchability from gastrointestinal nematodes by 80.7 and $82.3 \%$, respectively. For a higher concentration (2.8 $\left.\mathrm{mg} \mathrm{mL}^{-1}\right)$, the inhibition was similar $(80.3 \%)$
(Table 2). No statistical differences were observed for the leaf ketone extract at concentrations of 0.5 , 1,2 , and $2.8 \mathrm{mg} \mathrm{mL}^{-1}(\mathrm{p}>0.05)$.

Table 2. In vitro hatchability inhibition average \pm standard deviation of quadruplicate experiments of Mimosa caesalpinifolia leaf and stem ketone extract on the eggs of gastrointestinal nematodes of goats, after correction by the Abbott formula.

\begin{tabular}{ccc}
\hline Concentration $(\mathrm{mg} / \mathrm{mL})$ & Leaf ketone extract $(\%)$ & Leaf and stem ketone extract $(\%)$ \\
\hline 0.25 & $53.0 \pm 8.1 \mathrm{a}$ & $44.9 \pm 3.9 \mathrm{a}$ \\
0.5 & $78.3 \pm 4.0 \mathrm{~b}$ & $50.5 \pm 15.9 \mathrm{a}$ \\
1.0 & $80.7 \pm 10.6 \mathrm{~b}$ & $71.8 \pm 6.3 \mathrm{~b}$ \\
2.0 & $82.3 \pm 5.8 \mathrm{~b}$ & - \\
2.8 & $80.3 \pm 12.2 \mathrm{~b}$ & - \\
\hline
\end{tabular}

Values followed by lowercase letters on the same column were not significantly different by Tukey's test $(p>0.05)$.

The M. caesalpinifolia leaf and stem extract showed a lower inhibition rate than the leaf extract as the $\mathrm{CT}$ concentration in the leaf and stem material was lower (Table 1).

The extracts of tanniniferous plants have been demonstrated to have higher ovicidal and/or larvicidal activity than other extracts, depending on the structure of the CT monomers present in the plant (MOLAN et al., 2003). The anthelmintic activity of extracts can also be attributed to secondary metabolites other than CT. Compounds such as glycosides and flavonoids may play an important role in the anthelmintic activity (ADEMOLA et al., 2007; BARRAU et al., 2005). The chemical structure of these compounds is similar to the chemical structure of tannins, which suggested an identical or very similar action mechanism (ASSIS et al., 2003). Klongsiriwet et al. (2015) also showed that CT coupled with flavonoids (quercetin and luteolin) may exert a synergistic action against $H$. contortus. Thus, the identification of chemical components of plants is fundamental for the development of new drugs (ASSIS et al., 2003).

Egg hatchability inhibition has been demonstrated in the ketone extracts of tanniniferous plants (FERREIRA et al., 2013; OLIVEIRA et al., 2011a; VARGAS-MAGAÑA et al., 2014), although some conflicting results have been reported (ALONSO-DÍAZ et al., 2008; SULEIMAN et al., 2014). Moreover, different sources of CT have shown different efficiencies. No other chemical compounds could be identified in this study. However, the results of the inhibitory activity on egg hatchability of the gastrointestinal nematodes of goats confirmed the efficiency of the extracts tested.

The results of the artificial larval exsheathment of Trichostrongylidae of goats using the $M$. caesalpinifolia leaf are shown in Figure 1A. L3 larvae cuticular loss was observed during a 60-min exposure to a sodium hypochlorite solution of $M$. caesalpinifolia leaf ketone extract at 0.6 and $1.2 \mathrm{mg}$ $\mathrm{mL}^{-1}$ concentrations). No inhibition was observed at the concentration of $1.2 \mathrm{mg} \mathrm{mL}^{-1}+$ PVPP. PVPP was used as a tannin inhibitor to assess whether the latter was responsible for the larval exsheathment inhibitory effect. As the added concentration of PVPP was unable to inhibit the exsheathment it was concluded that cuticular loss inhibition was related to the action of CT in M. caesalpinifolia.

After a period of $60 \mathrm{~min}$, the M. caesalpinifolia leaf ketone extract inhibited the larval exsheathment of the mixed larvae $H$. contortus and T. colubriformis by 97.2 and $99.8 \%$, at 0.6 and $1.2 \mathrm{mg} \mathrm{mL}^{-1}$, respectively. 
Figure 1. Larval exsheathment inhibition of $M$. caesalpinifolia (A) leaf and (B) leaf and stem ketone extract in Trichostrongylidae of goats, after correction by the Abbott formula. ${ }^{*} \mathrm{P}<0.05$.
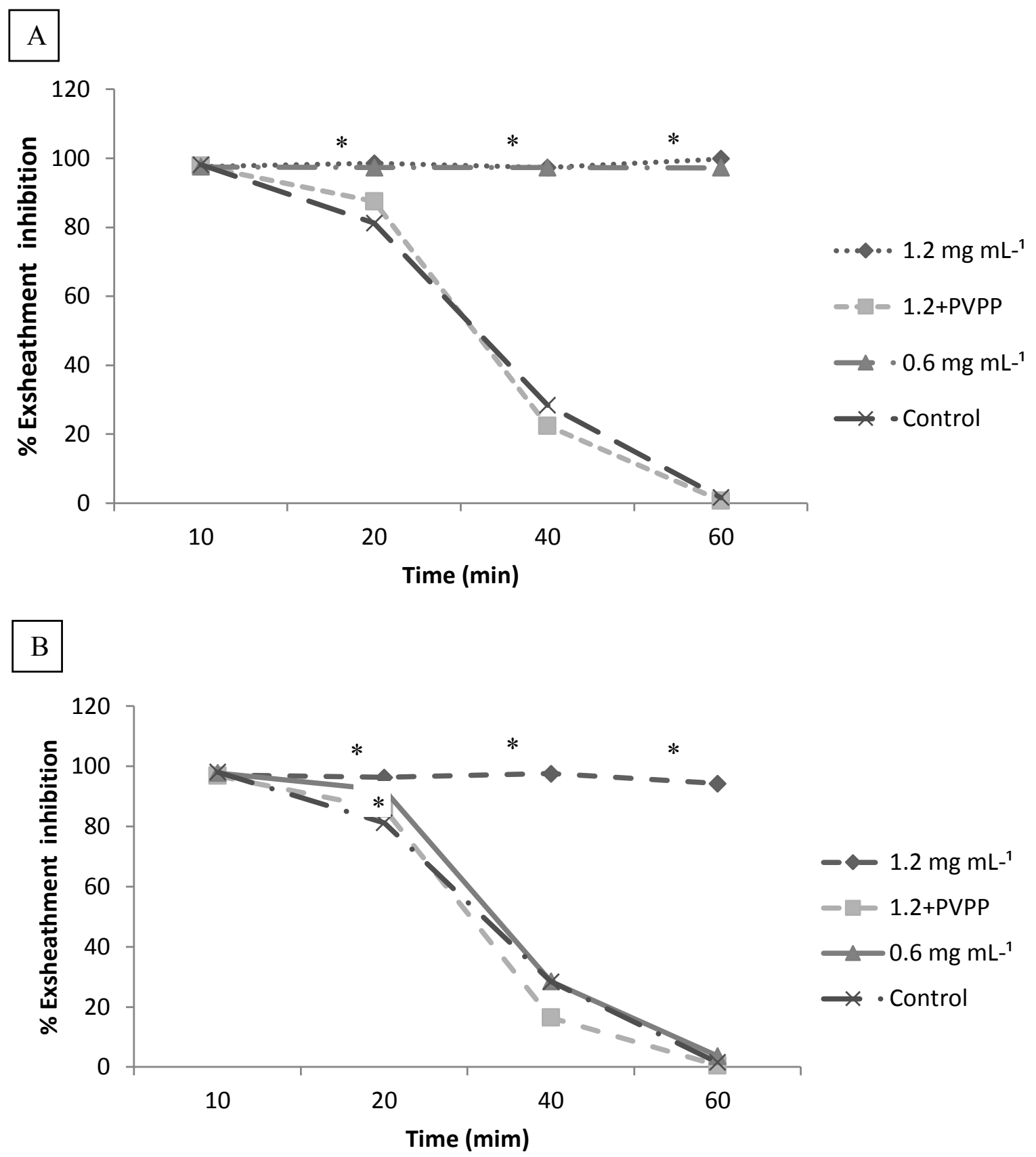

Oliveira et al. (2011b) obtained similar results in a study of the anthelmintic action of the leaf extract of Leucaena leucocephala and Mimosa tenuiflora: the extracts completely blocked the larval exsheathment of $H$. contortus. The essential oils of Alpinia zerumbet and Tagetes minuta at $10 \mathrm{mg} \mathrm{mL}^{-1}$ inhibited the larval development of $H$. contortus by 94.2 and $99.5 \%$, respectively (MACEDO et al., 2013).

The larvicidal action of Azadirachta indica (neem) extract on $H$. contortus larvae was assessed by Costa et al. (2008). The authors reported an $87.1 \%$ inhibition of larval development at $50 \mathrm{mg} \mathrm{mL}^{-1}$ of 
an ethanolic extract. At the same concentration, the ethyl acetate extract resulted in a $68.1 \%$ inhibition of larval exsheathment. The ethyl acetate extract of $A$. indica showed lower inhibitory activity than that found in this study for the M. caesalpinifolia leaf ketone extract. Marie-Magdeleine et al. (2014) studied larval development of $H$. contortus after treatment $M$. paradisiaca. The results demonstrated that the aqueous and methanolic extracts of $M$. paradisiaca leaf inhibited the development of $H$. contortus larvae by 77.4 and $98.7 \%$, respectively.

The results of the M. caesalpinifolia leaf and stem extract on $H$. contortus and $T$. colubriformis larvae are summarized in Figure 1B. It was observed that the cuticular loss was inhibited only at $1.2 \mathrm{mg} \mathrm{mL}^{-1}$ concentration and the results at concentrations of $0.6 \mathrm{mg} \mathrm{mL}^{-1}$ and $1.2 \mathrm{mg} \mathrm{mL}^{-1}+$ PVPP were similar to those for the negative control.

At $1.2 \mathrm{mg} \mathrm{mL}^{-1}$, the M. caesalpinifolia leaf and stem extract inhibited the larval exsheathment of the mixed larvae of $H$. contortus and $T$. colubriformis by $94.3 \%$, which was evidence of its action on the L3 larvae sheath. A previous study showed that extracts from the stem of the plants Anadenanthera colubrina, Leucaena leucocephala, and Mimosa tenuiflora, showed 100\% larval exsheathment inhibition on $H$. contortus after $60 \mathrm{~min}$. Furthermore, no inhibition of larvae exsheathment was observed for extracts with added PVPP, which was consistent with the results found in our study (OLIVEIRA et al., 2011b).

The IC50 values of the leaf and leaf and stems extracts for the larval exsheathment inhibition assay were 0.684 and $1.193 \mathrm{mg} \mathrm{mL}^{-1}$, respectively.

\section{Conclusions}

Mimosa caesalpinifolia leaf ketone extract showed ovicidal and larval exsheathment inhibitory activity on gastrointestinal nematodes of goats. The leaf and stem ketone extract of this plant, in turn, exhibited moderate inhibition of egg hatchability, but a high efficiency in the larval exsheathment assays was observed. These results indicated that in vivo studies should be performed to evaluate the activity of condensed tannins or other polyphenols isolated from sabiá (M. caesalpinifolia) on gastrointestinal nematodes of small ruminants.

\section{Acknowledgements}

The authors acknowledge the Federal Institute of Maranhão (IFMA), the Foundation for Research and Scientific and Technological Development of Maranhão (FAPEMA), and the Coordination for the Improvement of Higher Education Personnel (CAPES) for financial support.

\section{References}

ABBOTT, W. S. A method of computing the effectiveness of an insecticide. Journal of Economic Entomology, Annapolis, v. 18, n. 2, p. 265-266, 1925.

ADEMOLA, I. O.; FAGBEMI, B. O.; IDOWU, S. O. Anthelmintic activity of Spigelia anthelmia extract against gastrointestinal nematodes of sheep. Parasitology Research, Berlin, v. 101, n. 1, p. 63-69, 2007.

ALONSO-DÍAZ, M. A.; TORRES-ACOSTA, J. F. J; SANDOVAL-CASTRO, C. A.; AGUILARCABALLERO, A. J.; HOSTE, H. In vitro larval migration and kinetics of exsheathment of Haemonchus contortus exposed to four tropical tanniniferous plants. Veterinary Parasitology, Amsterdam, v. 153, n. 3-4, p. 313-319, 2008.

AMARANTE, A. F. T.; BAGNOL JUNIOR, J.; AMARANTE, M. R. V.; BARBOSA, M. A. Host specificity of sheep and cattle nematodes in São Paulo state, Brazil. Veterinary Parasitology, Amsterdam, v. 73, n. 1-2, p. 89-104, 1997.

ASSIS, L. M.; BEVILAQUA, C. M. L.; MORAIS, S. M; VIEIRA, L. S.; COSTA, C. T. C.; SOUZA, J. A. L. Ovicidal and larvicidal activity in vitro of Spigelia anthelmia Linn. extracts on Haemonchus contortus. Veterinary Parasitology, Amsterdam, v. 117, n. 1-2, p. 43-49, 2003.

BAHUAUD, D.; MARTINEZ-ORTIZ, M. C.; CHAUVEAU, S.; PREVOT, F.; TORRES-ACOSTA, F.; FOURASTE, I.; HOSTE, H. Effects of four tanniferous plant extracts on the in vitro exsheathment of third-stage 
larvae of parasitic nematodes. Parasitology, Cambridge, v. 132, n. 4, p. 545-554, 2006.

BARBOSA, H. P. Tabela de composição de alimentos do estado da Paraiba, "setor agropecuário". Areia: UFPB, 1997. $163 \mathrm{p}$.

BARRAU, E.; FABRE, N.; FOURASTE, I.; HOSTE, H. Effect of bioactive compounds from Sainfoin (Onobrychis viciifolia Scop.) on the in vitro larval migration of Haemonchus contortus: role of tannins and flavonol glycosides. Parasitology, Cambridge, v. 131, n. 4, p. 531-538, 2005.

BIZIMENYERA, E. S.; GITHIORI, J. B.; ELOFF, J. N.; SWAN, G. E. In vitro activity of Peltophorum africanum Sond. (Fabacea) extracts on the egg hatching and larval development of the parasitic nematode Trichostrongylus colubriformis. Veterinary Parasitology, Amsterdam, v. 142, n. 3-4, p. 336-343, 2006.

BLAKE, B.; COLES, G. C. Flock cull due to anthelminticresistant nematodes. Veterinary Record, London, v. 161, n. 1, p .36-36, 2007.

BRAGA, R. Plantas do Nordeste, especialmente do Ceará. 3. ed. Mossoró: ESAM, 1976. 540 p. (Coleção Mossoroense, 42).

COLES, G. C.; BAUER, C.; BORGSTEEDE, F. H. M.; GEERTS, S.; KLEI, T. R.; TAYLOR, M. A.; WALLER, P. J. World Association for the Advancement of Veterinary Parasitology (WAAVP) methods for the detection of anthelmintic resistance in nematodes of veterinary importance. Veterinary Parasitology, Amsterdam, v. 44, n. 1-2, p. 35-44, 1992.

COSTA JÚNIOR, G. S.; MENDONÇA, I. L.; CAMPELO, J. E. G.; CAVALCANTE, R. R.; FILHO, L. A. D.; NASCIMENTO, I. M. R.; ALMEIDA, E. C. S.; CHAVES, R. M. Efeito de vermifugação estratégica, com princípio ativo à base de ivermectina na incidência de parasitos gastrintestinais no rebanho caprino da UFPI. Ciência Animal Brasileira, Goiânia, v. 6, n. 4, p. 279-286, 2005.

COSTA, C. T. C.; BeVIlaQUA, C. M. L.; CAMURÇAVASCONCELOS, A. L. F.; MACIEL, M. V.; MORAIS, S. M.; CASTRO, C. M. S.; BRAGA, R. R.; OLIVEIRA, L. M. B. In vitro ovicidal larvicidal activity of Azadiractha indica extracts on Haemonchus contortus. Small Ruminant Research, Bet Dagan, v. 74, n. 1-3, p. 284-287, 2008.

COSTA, M. G. O sabiá mimosa caesalpiaefolia Benth. Areia: UFPB/CCA, 1983. 16 p. (Boletim técnico, 4).

FERREIRA, L. E.; CASTRO, P. M. N.; CHAGAS, A. C. S.; FRANÇA, S. C.; BELEBONI, R. O. In vitro anthelmintic activity of aqueous leaf extract of Annona muricata L. (Annonaceae) against Haemonchus contortus from sheep. Experimental Parasitology, Berlin, v. 134, n. 3, p. 327-332, 2013.

KAMINSKY, R.; GAUVRY, N.; SCHORDERET WEBER, S.; SKRIPSKY, T.; BOUVIER, J.; WENGER, A.; SCHROEDER, F.; DESAULES, Y.; HOTZ, R.; GOEBEL, T.; HOSKING, B. C.; PAUTRAT, F.; WIELAND-BERGHAUSEN, S.; DUCRA, Y. P. Identification of the amino-acetonitrile derivative monepantel (AAD 1566) as a new anthelmintic drug development candidate. Parasitology Research, Nova York, v. 103, n. 4, p. 931-939, 2008.

KLONGSIRIWET, C.; QUIJADA, J.; WILLIAMS, A.; MUELLER-HARVEY, I.; WILLIAMSON, E. M.; HOSTE, H. Synergistic inhibition of Haemonchus contortus exsheathment by flavonoid monomers and condensed tannins. International Journal for Parasitology: Drugs and Drug Resistance, St Lucia, v. 5, n. 3, p. 127-134, 2015.

LIMA, J. L. S. de. Plantas forrageiras das caatingas: usos e potencialidades. Petrolina: EMBRAPA-CPATSA, 1996. $43 \mathrm{p}$.

MACEDO, I. T. F.; OLIVEIRA, L. M. B.; CAMURCAVASCONCELOS, A. L. F.; RIBEIRO, W. L. C.; SANTOS, J. M. L.; MORAIS, S. M.; PAULA, H. C. B. de; BEVILAQUA, C. M. L. In vitro effects of Coriandrum sativum, Tagetes minuta, Alpinia zerumbet and Lantana camara essential oils on Haemonchus contortus. Revista Brasileira de Parasitologia Veterinária, Jaboticabal, v. 22, n. 4, p. 463-469, 2013.

MAIA, G. N. Caatinga: árvores e arbustos e suas utilidades. São Paulo: D e Z Computação Gráfica e Editora, 2004. 413 p.

MAKKAR, H. P. S. Effects and fate of tannins in ruminant animals, adaptation to tannins, and strategies to overcome detrimental effects of feeding tannin-rich feeds. Small Ruminant Research, Bet Dagan, v. 49, n. 3, p. 241-256, 2003.

MARIE-MAGDELEINE, C.; UDINO, L.; PHILIBERT, L.; BOCAGE, B.; ARCHIMEDE, H. In vitro effects of Musa x paradisiaca extracts on four developmental stages of Haemonchus contortus. Research in Veterinary Science, Roma, v. 96, n. 1, p. 127-132, 2014.

MOLAN, A. L.; MEAGHER, L. P.; SPENCER, P. A.; SIVAKUMARAN, S. Effect offlavan-3-ols on in vitro egg hatching, larval development and viability of infective larvae of Trichostrongylus colubriformis. International Journal for Parasitology, Victoria, v. 33, n. 14, p. 1691-1698, 2003. 
MUNN, E. A. Rational design of nematode vaccines: hidden antigens. International Journal for Parasitology, Victoria, v. 23, n. 4, p. 359-366, 1997.

OLIVEIRA, L. M. B.; BEVILAQUA, C. M. L.; IARA MACEDO, T. F.; MORAIS, S. M.; MONTEIRO, M. V. B.; CAMPELLO, C. C.; RIBEIRO, W. L. C.; BATISTA, E. K. F. Effect of six tropical tanniferous plant extracts on larval exsheathment of Haemonchus contortus. Revista Brasileira de Parasitologia Veterinária, Jaboticabal, v. 20, n. 2, p. 155-160, 2011b.

OLIVEIRA, L. M. B.; BEVILAQUA, C. M. L.; MACEDO, I. T. F.; MORAIS, S. M.; MACHADO, L. K. A.; CAMPELLO, C. C.; MESQUITA, M. A. Effects of Myracrodrum urundeuva extracts on egg hatchingand larval exsheathment of Haemonchus contortus. Parasitology Research, Nova York, v. 109, n. 3, p. 893898, 2011a.

PORTER, L. J.; HRSTICH, L. N.; CHAN, B. G. The conversion of proanthocyanidins and prodelphinidins to cyaniding and delphinidin. Phytochemistry, Washington, v. 25 , n. 1 , p. $223-230,1986$.
ROUTABOUL, J. M.; KERHOAS, L.; DEBEAUJON, I.; POURCEL, L.; CABOCHE, M.; EINHORN, J.; LEPINIEC, L. Flavonoid diversity and biosynthesis in seed of Arabidopsis thaliana. Planta Medica, Nova York, v. 224, n. 1, p. 96-107, 2006.

SULEIMAN, M. M.; MAMMAN, M. SIDIAMA, A.; IGHOJA, E. J.; TAUHEED, M.; TALBA, A. M. Evaluation of anthelmintic activity of Nigerian ethnoveterinary plants. Cassia occidentalis and Guiera senegalensis. Veterinary World, Wankaner, v. 7, n. 7, p. 536-541, 2014.

UENO, H., GONÇALVES, P. C. Manual para diagnóstico das Helmintoses de ruminantes. $4^{\text {th }}$ ed. Tókio: [s.n.], 1998. $143 \mathrm{p}$.

VARGAS-MAGAÑA， J. J.; TORRES-ACOSTA, J. F. J.; AGUILAR-CABALLERO, A. J.; SANDOVALCASTRO, C. A.; HOSTE, H.; CHAN-PÉREZ, J. I. Anthelmintic activity of acetone-water extracts against Haemonchus contortus eggs: Interactions between tannins and other plant secondary compounds. Veterinary Parasitology, Amsterdam, v. 206, n. 3-4, p. 322-327, 2014. 
